Caring for the Dead? An Alternative Perspective on Sámi Reburial

\author{
Asgeir Svestad
}

Department of Archaeology, History, Religious Studies and Theology, UiT - The Arctic University of Norway.

9037 Tromsø

Phone: +47 77646403 (work) /+47 99034517 (mobile)

Email: asgeir.svestad@uit.no 


\section{Caring for the Dead? An Alternative Perspective on Sámi Reburial ${ }^{1}$}

This article is an effort to critically discuss Sámi repatriation and reburial practice based on the analysis of five repatriation cases. Since the seminal repatriation (and burial) of the skulls of Somby and Hætta in Gávvuonna/Kåfjord in 1997, and the more recent reburial of 94 skeletons in Njauddâm/Neiden in 2011, a precedent seems established in Norway that allows the unconditional reburial of all Sámi human remains from collections and excavations. This inevitably poses a serious challenge to research on Sámi human remains and the Sámi past. It is argued that what is important is not research, but that Sámi are allowed to decide for themselves how they wish to care for the dead. Rather than argue according to the adversarial pro-research or pro-reburial viewpoints, this article will take a closer look at how the dead, and their associated material remains, are cared for during Sámi reburial. As will be argued, the care for the material side tends to be neglected and therefore raises an ethical question regarding this practice.

Keywords: Sámi repatriation and reburial; human and non-human remains; ethics; archaeology; materiality

\section{Introduction}

On November 21, 1997, the well-known repatriation and burial of the skulls of the Sámi religious activists Mons Aslaksen Somby and Aslak Jacobsen Hætta took place in Gávvuonna/Kåfjord ${ }^{2}$ in Alta in northernmost Norway. Somby and Hætta, who were affected by the puritan religious movement called Laestadianism, led a violent revolt against local authorities and the church in Guovdageaidnu/Kautokeino in the inner part of this region in 
1852. The revolt culminated in the flagellation of the priest Fredrik W. Hvoslef, robbery, arson, and brutal killings of the unscrupulous liquor dealer Carl Johan Ruth and detested Sheriff Lars Johan Bucht. Somby and Hætta were subsequently captured for these crimes by other Sámi, sentenced to death, and executed by decapitation in Alta in $1854 .{ }^{3}$ After their execution, their skulls were included as the first Sámi specimens in the university collection at the Anatomical Institute in Oslo (now the Schreiner Collection), while their bodies were buried in unconsecrated ground outside the Gávvuonna/Kåfjord churchyard because the interred were convicted murderers. This was done in spite of the new Criminal Law of 1842 that repealed the injunction of the burial of executed people in churchyards (Drivenes and Jernsletten 1994; Bull 1996; Zorgdrager 1997; Schanche 2002a).

The request for the burial of Hætta and Somby's crania came about after a long struggle, during which demands were forwarded by relatives as early as 1976 (Schanche 2002a, 110). Eventually, the case was taken up by the Norwegian Sámi Parliament and the skulls were removed from their repositories in Copenhagen and Oslo, respectively. ${ }^{4}$ To prepare for burial, the skulls were placed in miniature pulka (sled)-like containers made for the occasion, imitating pre-Christian Sámi burial customs (Figure 1). They were then buried in the assumed same location as the bodies, outside the churchyard of the Kåfjord Church (Figure 2). During the burial ceremony, the county governor of Finnmark apologized on behalf of the Norwegian State for collecting Sámi human remains for research purposes. However, Niillas Somby, a driving force and spokesperson in the case, and one of the relatives who first demanded repatriation, did not attend the ceremony because he claimed the remains were given a Christian service and thus did not represent the beliefs and attitudes of Mons Aslaksen Somby and Aslak Jacobsen Hætta (Simma 1999). In contrast to his view stand the last words of Hætta: “Lord Jesus answer me!” (Wetlesen [1854] 1997, trans. Svestad; cf. Hvoslef in Smith 1938, 494-496). ${ }^{5}$ 
[Figure 1 and 2 to be placed about here]

The cause(s) behind the Kautokeino revolt have been the subject of numerous scholarly, as well as unscholarly, inquiries (see, e.g. Turi 1911; Aikio 1914; Steen 1965; Kristiansen 1970; Bjørklund 1992, 2008; Drivenes and Jernsletten 1994; Hirsti 1994; Bull 1996; Zorgdrager 1997; Aarseth 2000; Andresen 2007; Christensen 2012; Ballari 2013). The perception that events were caused by a complex set of religious factors, judicial factors, and social significance seems to prevail in later research, although the justification of their actions is still contested. Notwithstanding, the repatriation (and reburial) issue is an emotional and sensitive matter, given Sámi suppression during the colonialist era of the nineteenth and twentieth centuries, during which the collecting of Sámi human remains was undertaken. Based on this background, the burial in Gávvuonna/Kåfjord was a strong symbolic and political manifestation of the long-standing injustice towards the Sámi as indigenous people of Norway and Fennoscandia, as well as marking an end to nearly 150 years of grief for the families of Hætta and Somby.

In retrospect, the Gávvuonna/Kåfjord case highlights obstacles of ethical significance related to the Sámi repatriation and reburial issue, such as how to handle opposing indigenous interests regarding religious beliefs and burial customs. One may also question the way the burial and the remains themselves were handled, given the ad hoc blend of Christian and preChristian burial customs and the somewhat accidental location of the burial place of Somby and Hætta, since there is no evidence that corroborates the burial of their skulls in the same area let alone the same graves as their post-cranial remains. Consequently, their skulls may have been buried in other individuals' graves. Similar practices are revealed in other Sámi repatriations and reburials; namely, the beliefs and burial customs are often clouded, or 
absent, and the handling of human and non-human remains is rather accidental and scarcely subject to any scrutiny or discussion. Thus, it appears that the remains mainly seem valued as a means to pay for the consequences of history, or to make up for loss of identity, while the remains in themselves - their qualities - largely seem silenced or ignored. There is a lack of emphasis on what remains, as well as its character and historical significance.

The ethical debate in repatriation and reburial cases is mostly devoted to the question of legitimacy, and not to the act itself. That is, the ethical debate takes place before the actual reburial process and handling of remains. In the conventional understanding of ethics, it seems that only certain aspects of repatriation and heritage practices are given ethical concern, while others are not. Thus, the question is, where do we draw the line? Which phenomena may be subject to ethical claims, and which may not? Should the reburial act and handling of the remains be made subject to ethical concerns?

With regard to scholarly perspectives and indigenous stances on repatriation and reburial as important decolonization practices (e.g. Mihesuah 2000; Fforde, Hubert, and Turnbull 2002), ethical questions regarding the reburial act itself seem to touch upon a theme beyond questioning. It is no exaggeration to say that the agenda of what is considered ethically appropriate (and relevant) is strongly constrained by debates in the archaeology and cultural anthropology of the Anglo-American or English-speaking world, particularly with reference to the brutal and violent history towards Native Americans and Australian Aborigines (cf., e.g. Svestad 2013b; Karlsson 2013; Aronsson 2013; Goldstein 2013; Zimmerman 2013). This history is acknowledged, but one should be cautious in ascribing universal relevance to ethics grounded on local or regional contexts (cf. Nilsson-Stutz 2013: González-Ruibal 2018). Ethics may vary between indigenous groups; that is, what may be unethical to one group may be ethical to another (see, e.g. Pickering 2011). This makes it necessary to evaluate each context on its own grounds (for a similar critique, see Ferris and 
Welsh 2015, 70-71), which implies that the perspective forwarded here is first and foremost maintained towards a Sámi and Fennoscandian context. This instance may imply incommensurability on ethics.

The intention here is not to be insensitive towards indigenous people, nor to contest the legitimacy of reburial, but to call attention to a concern for human and non-human remains that seems to have been quite absent during the debates on Sámi repatriation and reburial, as well as in international debates on the repatriation issue (see, however, Svestad 2013a). This perspective emanates from the thing-theoretical discourse, which has developed in the social sciences and humanities (including archaeology) in the last decades (see, e.g. Latour 1999; Preda 1999; Brown 2001; Olsen 2003, 2010; Domanska 2006; González-Ruibal 2008; Webmoor and Witmore 2008; Graves-Brown 2011; Hodder 2012; Pétursdóttir 2012; Pétursdóttir and Olsen 2017). Grounded in the critique of anthropocentrism, the being of things and our entanglements with the material world are core elements of this ontological theorizing. Of particular relevance here is the emphasis on the ethical concern for things and materiality, and the critique of calculative thinking and mere valuing of things for human utility (cf. Benso 2000; Introna 2009; Olsen et al. 2012; Pétursdóttir 2013; Svestad 2013a; Sørensen 2013; Olsen and Pétursdóttir 2016; Gonzáles-Ruibal 2018).

Thus, the aim of this article is to call attention to the quality and being of materiality and things in Sámi repatriation and reburial; more precisely, how the dead and the associated (non-human) remains themselves are being cared for. A further goal is to theorize and discuss which ethical consequences the alleged neglect of human and non-human remains may bring about. This perspective is aligned with a recent critique of heritage studies, which stresses that the ethics of cultural heritage should acknowledge that things and places themselves should be made the source of their own significance, and not only considered valuable and meaningful as part of present-day cultural processes and activities (Olsen et al. 2012, 201; 
Solli 2011; Pétursdóttir 2013). Although this may appear to be vague metaphysics, this article will in a similar way emphasize the intrinsic values and ethical signification of human and non-human remains (cf. Benso 2000, xxx). What thing-theory brings to the table is not only a concern for human remains and how they are handled, which automatically would be associated with ethics, but a concern for the associated material remains, their character and qualities, and how they are taken care of in Sámi repatriation and reburial. Given their intimacy with human remains, and as manifestations of the dead's identity and persona, the handling of both human and non-human remains should have ethical consequences.

In forwarding these objectives, the article will elaborate on my case study of the Njauddâm/Neiden reburial (Svestad 2013a) - which emphasized a similar objective - by comparing that case to four other Sámi repatriation/reburial cases (including the Gávvuonna/Kåfjord burial). The cases, which will be presented at the beginning of the article, are in many ways diverse and were chosen to reflect the complexity of Sámi repatriation and reburial, rather than being regarded as representative of the whole. They will then be used as a backdrop for theorizing the ethics of the materiality of past and present in Sámi repatriation and reburial. Before turning to the cases, it is necessary to dwell slightly on the archaeological relevance of the repatriation and reburial issue, since it may be argued from the start that repatriation is not for archaeologists, but only serves the needs of indigenous concerns.

\section{Why Care What Archaeologists Think?}

The orthodox point of departure in the reburial issue is that reburials are primarily for the living and what the living think, and how the living wish to care for the dead, which, however, may be extended to all burials (i.e. also original burials). Consequently, one may argue that repatriation or reburial automatically implies the respect and care for the dead, as long as their remains are being handled according to the wishes of descendants or 
representatives of the indigenous group. Accordingly, it should be up to the indigenous community to unconditionally determine how reburial should take place. Based on this background, criticism of indigenous repatriation and reburial practices seems ethically inappropriate, unless raised by indigenous peoples themselves. How indigenous people decide to bury the returned dead varies, and how and why they do this is an important and sensitive topic that requires understanding of peoples' decisions and challenges. Moreover, should indigenous peoples not be allowed to decide for themselves what is ethically important or not (cf., e.g., Mihesuah 2000; Fforde, Hubert, and Turnbull 2002; Schanche 2002a)? Who are archaeologists to decide about indigenous peoples' concern for the remains of their ancestors? Making critical remarks on the issue is difficult and not without a certain risk of being judged as an elitist scientist who carries on colonial research with doubtful moral values (Svestad 2013a, 2013b; Karlsson 2013). Articles on this theme can face difficulties in being published, as has been the experience with this paper. Nevertheless, the reburial issue brings out a variety of opinions within indigenous groups and its varied practices raise questions regarding how ethics are to be understood. For example, should burial practice remain static (reflecting a sense of time immemorial) or are new ceremonies that combine elements of old and new traditional practice acceptable or disrespectful? Thus, given the emphasis on the ancestor's religious beliefs and burial customs, one may question how they correspond to the stance of unconditional determination of reburial procedures by descendant indigenous communities (cf. the Vermillion Accord). What about instances where beliefs and customs are unknown, which applies to most of the cases discussed in this context? What about opposing views among descendants with regard to the handling of the remains, as for instance in the Gávvuonna/Kåfjord case?

However, as pointed out by Liv Nilsson Stutz $(2008,90)$ and other scholars (e.g. Thomas 2000), archaeologists often find themselves caught in the middle, feeling a 
responsibility for the mistakes of our predecessors and a sympathy for the rights and emotional needs of marginalized and oppressed indigenous peoples on the one hand, and our responsibility to the discipline of archaeology on the other. This implies divided concerns for redressing colonial violations and archaeological responsibilities for cultural heritage. The thing-theoretical perspective of this article is an attempt to present an alternative view, and in a way transcend this dilemma with its emphasis on caring for the dead. Thus, one may ask whether it is not imperative to know the dead and their human and non-human remains, to disclose aspects of them, their date, origin and state, as preconditions of caring for the dead? All things considered, are such concerns ethically irrelevant? Moreover, as questioned by Ewa Domanska $(2006,347)$, are the dead only important insofar as they serve or can be utilized by the living, "not least, as objects of the work of mourning"? Or, one may add, as objects for penitential exercises? Finally, is showing respect for the dead the same as caring for them?

Taking these questions into consideration, archaeology - claimed to be the discipline of things per se (e.g. Olsen 2003) - may be perceived as a particular field suited for evaluating the care of human and non-human remains in bringing forth aspects of their material presence (and absence), individuality and history. With these reflections in mind, let us now turn to the actual cases.

\section{Sámi Repatriation and Reburial Cases}

The collecting of Sámi human remains primarily happened in pre-Christian and Christian graves and cemeteries from most Sámi areas of Fennoscandia between c. 1820 and 1940. This activity often occurred with no or little respect for the wishes, objections, and feelings of descendants and local communities, although there were nuances that included Sámi involvements (see, e.g., Isaksson 2000; Schanche 2000, 2002b; Sellevold 2002; Svestad 2007, 2013a, 2017; Ojala 2009). The emergence of the Sámi repatriation and reburial issue is 
closely related to the people's struggle for rights (including rights to their own past and heritage), democratization, and self-determination that particularly emerged during the $1980 \mathrm{~s}$ and 1990s (see, e.g., Minde 2001, 2003). The Gávvuonna/Kåfjord repatriation and burial had a decisive impact on this issue, although the earliest known Sámi reburial happened in the early 1960 s.

Altogether, there have been approximately 15 cases dealing with claims or requests of repatriation of Sámi human remains (see, e.g. Schanche 2002a, 2002b; Sellevold 2002; Iregren 2002, 2010; Lehtola 2005; Harlin 2008a; Nilsson Stutz 2007/2008, 2008; Mulk 2009; Ojala 2009; Masterton 2010; Holand and Sommerseth 2013; Aronsson 2013; Svestad 2013a). Seven of the repatriation claims ended in reburials, three are anticipating reburial, two resulted in repository of the human remains with Sámi museums, one is awaiting repository due to a decision of the Swedish Sámi Parliament, and two are awaiting management and decision by authorities (Harlin 2008a; Mulk 2009; Iregren 2010; Hedlund 2011; Sveriges Radio 2011; Aronsson 2013; Karlsen 2014; Paulsen and Andersen 2014; Skotnes 2016; Assmundsson 2016; Liedgren 2016; Ojala 2016; Svestad 2018). ${ }^{6}$ In the following section, a brief account of four of the reburials is presented. They include Gamla Kyrknäset, Jaamišsuálui/Vanhahautuumaasaari, Sierkejukke/Risbäcken, and Njauddâm/Neiden (Figure 3) (the Gávvuonna/Kåfjord case is already sufficiently presented and will only be included in the discussion).

[Figure 3 to be inserted about here]

\section{Gamla Kyrknäset}

The first and least known reburial of Sámi human remains took place in the closed-down cemetery of Gamla Kyrknäset (ca. 1762-1850, cf. Grahn 2012) in the village of 
Dearna/Tärnaby in northern Sweden in 1963. In the outskirts of the churchyard, human remains of approximately 25 individuals were reburied in a communal grave marked with a memorial stone (Figure 4). The remains originated from the early Christian Sámi cemetery of Vila (former Hwila) Chapel (ca. 1723-1762) in Vilasund some $50 \mathrm{~km}$ farther north, which is the earliest Sámi churchyard in the region. In 1962-63, the cemetery was the focus of an archaeological mitigation ahead of damming the surrounding lakes and subsequent transgression of the site. ${ }^{7}$ The archaeological documentation from this excavation is incomplete, but it is evident the dead were wrapped in woollen cloth, birch bark or pelt, and interred in pulkas (Sámi sleighs). Associated funerary objects included strike-a-lights, firestones, knives, and in one instance, reindeer antler pieces (Zachrisson 1976, 118-119; Meschke 1977, 80; Svestad 2007, 56; Iregren 2010, 57). The mortuary practice resembled pre-Christian Sámi burial customs and suggests there was no clear break with pre-Christian Sámi religious practices (Manker 1961; Schanche 2000; Svestad 2007, 2011).

[Figure 4 to be inserted about here]

The reburial ceremony at Gamla Kyrknäset is poorly known. However, the abovementioned funerary objects found in graves were not included with the reburial, which was carried out by the local priest of the Dearna/Tärnaby congregation. The Swedish National Heritage Board (RAÄ) that handled the case in the early 1960s allegedly lack information in their archives, although according to Margareta Biörnstad, the curator in charge at the RA $\ddot{A}$ at the time (and present during the excavation), demand for reburial was pursued by local Sámi who opposed archaeological excavation and instead wanted the cemetery to be undisturbed and transgressed by water (personal communication, August 13, 2014). The RAÄ complied with the demand, in part because the skeletons were poorly preserved. The human remains did 
not undergo a detailed osteological analysis, with the exception of five mandibles analysed by Tandläkarhögskolan in Umeå (presently the Odontology Department, Umeå University), which still houses the mandibles (Elisabeth Iregren, personal communication, August 13, 2014; cf. Iregren 2002, 87; 2010, 57).

\section{Jaamišsuálui/Vanhahautuumaasaari}

On Jaamišsuálui/Vanhahautuumaasaari (the Island of the Dead) in Lake Aanaar/Inari in northern Finland, a communal reburial of 95 Sámi skulls took place on July 16, 1995 (Harlin 2008a, 196) (Figure 5). The island's cemetery belonged to seventeenth- and eighteenthcentury mainland churches of Pielpajärvi and was in use as a Sámi cemetery from around 1700 until 1793 (Arponen 1993). Its origin, however, is ambiguous. The cemetery may have been in use prior to the Christian period, similar to other early Christian Sámi cemeteries (Svestad 2011). In the late nineteenth and early twentieth century, more than 170 skulls were excavated in the Aanaar/Inari area and included in racial studies in physical anthropology in a programme at the Finnish Academy of Science and Letters (Isaksson 2000). The programme had permission to excavate from governmental authorities and the Finnish Church. According to a memorial plate on the reburial site, the skulls were collected from graves on the island for scientific purposes (Figure 6). However, it is unknown whether all the reburied remains originated from this island cemetery. According to Aki Arponen (1993, 12-13; Näätänen 1936, 46-47; Kemiläinen 1998, 166; Isaksson 2000, 198; Lehtola 2005, 84), it is likely that skulls from Sámi graves and cemeteries elsewhere in Lake Aanaar/Inari and northern Finland were also included in the reburial. Some skulls may even represent non-Sámi.

[Figures 5 and 6 to be inserted about here] 
The repatriation process happened quickly and in obscurity, with little documentation, but the reburial was apparently given a Christian ceremony led by a local priest. Apart from the osteological analysis by physical anthropologists in the early twentieth century, nothing is known about the context of the human remains, and whether artefacts were excavated from graves and remain in museum collections.

\section{Sierkejukke/Risbäcken}

Reburial of remains presumed to be the South Sámi man named Soejvengeelle ("the Shadow Man") is one of the most well-known Sámi repatriations. The reburial took place on October 11, 2002 at Sierkejukke/Risbäcken near the mountain of Aatoeklibpie/Atoklinten in Tärna in northern Sweden (Figure 7). Soejvengeelle was a real man who lived during the nineteenth century, and of whom several myths still existed in 1950, when a minor archaeological investigation was carried out by ethnologist Ernst Manker on what was believed to be this man's grave (Manker 1961, 157-158) (Figure 8). Following the excavation, Manker brought some of the human and other remains from the grave to Nordiska Museet (Nordic Museum) in Stockholm, but he promised to return them after analysis. For unknown reasons, however, Manker never kept his promise. In 1999, the local Sámi association Vadtejen Saemiej Sijte of Dearna/Tärna made a claim of these remains, which eventually ended in reburial of the remains in the same grave as they originated (Heinerud 2002/2004). Before reburial, an archaeological reinvestigation was carried out and a bone sample radiocarbon-dated in order to collect additional information of the grave's content, construction, and age (Heinerud 2002/2004, cf. 2011). The grave appears to have consisted of erect stone slabs placed towards one another to form an oblong stone-slab construction (with a triangular cross-section) above the body (Figure 9). Manker $(1961,157)$ describes how he documented fragments of birch bark and what he considered to be a board of a pulka underneath the collapsed stone slabs, 
which he interpreted as evidence of the man being placed in a pulka on a layer of birch bark, analogous with pre-Christian Sámi burial customs. He also described how the grave was constructed directly on the ground surface. According to Manker, the grave had been disturbed, likely by youngsters who had "investigated" the grave some years earlier. At this time, they also observed a knife and an axe interred with the human remains (Manker 1961, 158).

[Figures 7-9 to be inserted about here]

The results of radiocarbon dating of the human remains yielded a calibrated age of mid-fifteenth century, and clearly did not correspond to the nineteenth century date for Soejvengeelle (Heinerud 2002/2004:9). Reinvestigation also revealed the grave had been disturbed several times over the centuries, which made it difficult to reassess Manker's (1961, 159) reconstruction. An axe of unknown age and a broken knife dated to the late Mediaeval Period, or later (and probably objects described by the youngsters), were also recovered, along with remaining bones and teeth of the individual not originally collected. A number of twentieth-century coins were also collected, and probably represent later "offerings" to Soejvengeelle. No remains of the alleged pulka, or wood, were found. Only some fragments of birch bark were found and discarded (Heinerud 2002/2004, 9).

According to the wishes of the local Sámi association, the human remains should be lain on a pelt of reindeer in a new pulka together with the axe and the knife, placed on a layer of birch bark and then covered with birch bark for protection (Heinerud 2004/2004, 2). The birch bark fragments and possible board of a pulka, which Manker brought to Stockholm, could not be retrieved and were not reburied. To prevent damage and secure the grave, the Sámi association further requested the pulka be dug into the ground and covered with heavy 
stone slabs with soil on top of the birch bark layer. Finally, the grave should be reconstructed according to Manker's description (believed to be close to the original construction) and include a new mid-beam to carry the stone slabs (Manker 1961, 159). A simple ceremony was performed during reburial (Heinerud 2002/2004).

\section{Njauddâm/Neiden}

By far the largest repatriation of Sámi human remains took place in the small Skolt Sámi village of Njauddâm/Neiden in the municipality of Sør-Varanger in northern Norway on September 25, 2011 (Figure 10). In close proximity to the well-known Orthodox cemetery of Njauddâm/Neiden, the human remains of 94 Skolt Sámi were reburied following the demands forwarded by the local Orthodox congregation. The human remains were excavated in 1915 by the physician and odontologist Johan Brun from an unknown cemetery near the Orthodox Skolt Chapel in Njauddâm/Neiden. They were thereafter included in the anatomical collection at the Institute of Anatomy (now the Schreiner Collection) at the University of Oslo. Brun was commissioned by the head of the institute, anatomist Kristian Emil Schreiner, who provided legal permission for the excavation from Norwegian authorities as part of a project to investigate the anthropology of the Sámi (Holck 1990). Along with the skeletons, Brun also documented funerary objects in some graves, which he brought back with the human remains. The excavation was carried out amidst protests from some of the local Skolt Sámi, one of whom was an old woman and the ecclesiastical leader of the small congregation. However, not all local Skolt Sámi made explicit objections to the excavation. One of them, Ondre Jacobovitsj, even contributed significantly by pointing out the old cemetery and charging Brun a fairly large sum of money for each skeleton of his ancestors (Svestad 2013a, 208).

[Figure 10 to be inserted about here]. 
Following the demand for reburial, this case created significant controversy involving different stakeholders, such as Sámi politicians, Skolt Sámi, other Sámi and non-Sámi. However, a major group of local Skolt Sámi opposed reburial and the way the case was carried out. They argued instead for preservation of the human remains for research and knowledge of their forefathers, and to postpone the question of reburial.

Before reburial, a brief skeletal documentation was carried out and 10 randomly selected bone samples were radiocarbon-dated. In addition, small samples were taken from the skeletons for future research. The dates were mostly from the Mediaeval Period, or earlier than the supposed beginning of Skolt Sámi Christianization, which likely took place from the latter half of the sixteenth century. A geophysical investigation with ground-penetrating radar (GPR) noted what appeared to be numerous undisturbed burials oriented north-south, which lends additional credence to a pre-Christian date for the cemetery because Christian burials are typically east-west (Paasche and Trinks 2010; Svestad 2013a, 210).

The reburial took place on a cleared site near the area where the skeletons were excavated. Each skeleton was placed in a small wooden coffin in a circular, communal grave forming the shape of a large burial mound (Figure 11). The funerary objects recovered from graves, however, were not reburied and are currently stored at various museums. The reburial was carried out with an Orthodox Christian ceremony (cf. Figure 10).

[Figure 11 to be inserted about here]

\section{Re-Establishing the Dignity of the Dead}

In general, the cases presented are considered important manifestations in making up for past wrongs against the Sámi people. As pointed out by Audhild Schanche (2002c, 124-125), 
former repatriation expert in the Norwegian Sámi parliament, a desire to pay for the consequences of history has motivated decisions made in Sámi repatriation cases. The indigenous Sámi have the right to manage their own cultural heritage, from which human remains and religious objects manifest both painful experiences of historical loss and symbolize an opportunity to re-establish spiritual and physical dignity. Schanche's perspective adds to the concept of decolonization and the undoing of colonialism through repatriation and reburial in an effort to free both the dead and the living of colonial impact and heritage.

A number of works within archaeology, social anthropology, and other disciplines have emphasized repatriation and reburial as significant decolonizing practices with respect to indigenous people's rights to their own past and cultural heritage (see, e.g. Zimmerman 1989; Swindler et al. 1997; Smith 1999; Mihesuah 2000; Fforde, Hubert, and Turnbull 2002; Smith and Wobst 2005; Bruchac, Hart, and Wobst 2010). This emphasis is closely related to perspectives on ethics in archaeology (see, e.g. Lynott and Wylie 2000; Zimmerman, Vitelli, and Hollowell-Zimmer 2003; Karlsson 2004; Scarre and Scarre 2006; Vitelli and ColwellChanthaphonh 2006; Hamilakis and Duke 2007; Colwell-Chanthaphonh, Hollowell, and McGill 2008). Further, in the international discourse related to repatriation, reburial and heritage more generally, the unity, identity, authenticity and in situ conservation appear to be key concerns (Brattli 2009; Harrison 2012; Meskell 2010, 2012; Nilsson Stutz 2013). As stated by Nilsson Stutz $(2013,175)$, for instance, the repatriation of human remains plays a crucial role in contemporary identity politics and may as such become a very effective tool for the production of identity for the group involved. Similar concerns are reflected in various ways in the discourse on these issues in relation to Sámi contexts (see, e.g. Sellevold 2002; Schanche 2002a, 2002b, 2002c; Falck and Skandfer 2004; Holand 2004; Lehtola 2005; Stångberg 2005; Harlin 2008a, 2008b; Nilsson Stutz 2008; Mulk 2009; Ojala 2009, 2016); 
Nordberg and Fossum 2011; Ween 2012; Fossheim 2013; Skjeggedal and Overvåg 2017). In extension of this debate, and turning to the cases above and the objective of this article, one may ask in what way the dead's unity, identity, spiritual and physical dignity are restored or re-established, and in what way reburial represents in situ conservations.

The symbolic value of reburial appears to be of fundamental significance in all cases. This appears to automatically imply the re-establishment of respect or dignity for the dead. This is perhaps most evident in the burial of Somby and Hætta and the reburial of the man at Sierkejukke/Risbäcken, but is also present for the other reburials. Bringing the human remains back to the place where they were once buried might be claimed to be a means of reestablishing the identity of the dead and their unity with the living, even though it is rarely possible for them to be reinterred in the original grave or cemetery (e.g. reburials at Gamla Kyrknäset, Jaamišsuálui/Vanhahautuumaasaari, and Njauddâm/Neiden). Still, one might claim the dead are brought back to a cemetery and indigenous sphere where they naturally belong. As stated above for the Gávvuonna/Kåfjord case, the skulls were allegedly buried in the same place as their bodies. The skulls were also placed in "genuine" Sámi containers, that is, miniature pulkas, and the humanity and indigenousness they were deprived of in both life and death may in this way be perceived as having been restored. In the Sierkejukke/Risbäcken case, a thorough reinvestigation, radiocarbon dating, and collecting of historical information resulted in a detailed reconstruction of the original grave context. The axe and knife associated with the human remains, and the later deposited coins, were all included with the reburial. In this case, the collaboration between archaeologists, local Sámi, and official authorities appears to be a model for Sámi repatriation and reburial. Further, the care for the deceased seems to have been a central aspect in the handling of the burial of Somby and Hætta and the reburial at Sierkejukke/Risbäcken, which included protective physical arrangements and alleged emphasis on the well-being of the human remains. 
In the latter case, the human remains were placed on a reindeer pelt in a newly made pulka. It is likely the individual's remains were originally placed in a pulka in the manner in which Manker interpreted the wooden remains. A similar use of pulkas is evident in both preChristian and Christian times, although predominantly a pre-Christian Sámi burial practice (Manker 1961; Schanche 2000; Svestad 2011). ${ }^{8}$ However, wooden coffins were also used in pre-Christian times, but this feature varies among regions and even within the same cemetery (cf. Manker 1961; Ovsiannikov 1993; Schanche 2000; Svestad 2007, 2011). Placing the deceased person on a reindeer pelt is only known from an eleventh-century allegedly preChristian hybrid Sámi-Norse grave at Skjoldehamn in North Norway (Svestad 2017). Reindeer pelt fragments were not documented during either Manker's excavation or the re-excavation at Sierkejukke/Risbäcken, which raises questions about why reindeer pelt was included in the reburial. It is, however, possible that the reindeer pelts had already decomposed by the time the individual was excavated, making this a question of taphonomy. In any case, one may further question the way birch bark was added to the grave. The use of birch bark is a distinct pre-Christian feature that varies through time and among various Sámi regions, but it also occurs occasionally in Christian Sámi graves (Manker 1961; Zachrisson 1976; Schanche 2000; Svestad 2007, 2011). Fragments of birch bark were documented in both investigations of the grave at Sierkejukke/Risbäcken but were not included in the reburial. The fragments taken by Manker could not be retrieved, and those documented during the reinvestigation were discarded. Manker interpreted the fragments of birch as a layer on the ground beneath the pulka. However, during reburial, sheets of birch bark were placed both above and beneath the pulka as means of protection. Moreover, and in contrast to the original burial practice, the pulka was dug into the ground and then covered with soil and heavy stone slabs on top of the upper birch bark layer. Generally, pre-Christian Sámi graves were not dug into the ground, which to a certain extent corresponds to pre-Christian Sámi beliefs 
concerning the spirits of the ancestors and their free movement between the world of the living and the world of the dead (e.g. Itkonen 1946; Pettersson 1957; cf. Schanche 2000, 260-264).

The grave itself, including the human remains and the remains of the funerary objects, was severely decomposed at the time of Manker's investigation. A few human bones, an alleged pulka board, numerous birch bark fragments, parts of an axe, and a knife remained underneath the grave's collapsed stone-slab construction. After around 500 years, the grave and its contents were well along in the process of decomposition. This taphonomic process of death and decay is intrinsic to a grave and also defines the particular ontological condition of remains themselves. Thus, given the significance of re-establishing the respect for the ancestors in indigenous repatriation and reburial, should the remains not be allowed to continue their decaying process as they were? Why do the remaining things, such as fragmented skeletal remains and artefacts and the collapsed grave, need to be given a new shape as if they represented a new burial or being? Is the placement of the remains on a soft reindeer pelt in a newly made pulka covered with a new layer of birch bark and a reconstructed stone slab structure in care of the deceased? Or is this a care mainly offered to the living performing the ceremony, to make the dead more complete and indigenous? Moreover, why do remains of the dead need protection and why add new features, such as a trench in the ground and sand and stones on top of the pulka? Is this what is meant by in situ conservation? Accordingly, why did the archaeologists discard the birch bark fragments as waste? Should the remains, as they were, be allowed to continue the process of decay? Is this not an inevitable aspect of death and caring for the dead?

In contrast to these questions, one may argue that the Sámi created a ritual that was meaningful then and there, defining the dead as Sámi through the inclusion of significant elements. In this way, they demonstrated deep respect for their ancestors. Hence, given the 
significance of rituals, the factual condition of human and non-human remains brought forward by archaeologists may be perceived irrelevant. Still, respect for the dead is necessarily not equal to caring for their remains in this context; that is, to care about, provide for and take care of them.

The reburials at Gamla Kyrknäset, Jaamišsuálui/Vanhahautuumaasaari, and Njauddâm/Neiden demonstrate a similar procedure to the reburial of the remains at Sierkejukke/Risbäcken, but the interest in and care for the human remains and the things themselves might be perceived as being more absent. The handling and decisions made in the reburial at Gamla Kyrknäset are not sufficiently elucidated, but it appears the reburial did not follow what is known of traditional burial customs of the Vila Churchyard, where the human remains originated. Instead the human remains were given an identical reburial in a communal grave and separated from their associated funerary objects, such as strike-a-lights, firestones, knives, reindeer pelt, cloth, and other things that remain in the museum collections. With regard to the reburial at Jaamišsuálui/Vanhahautuumaasaari, which appears to have happened in a hurry, there is reason to believe several of the individuals did not originate from this particular cemetery, and some may have been non-Sámi. It has not been possible to determine at this time whether there were objects recovered from the graves during excavations at Jaamišsuálui/Vanhahautuumaasaari, and whether these are still in museums, . It appears, however, that only human remains were part of the reburial. In the Njauddâm/Neiden communal reburial, human remains of 94 individuals were placed in newly constructed small, wooden coffins and given an identical Christian reburial. Before this decision was made, it was known that the remains had not been buried in the same way and were not from the same cemetery. Many, or perhaps the majority, were most likely nonChristians (cf. Svestad 2013a, 210). In addition, objects recovered from some of these graves, such as cruciform pendants, fragments of birch bark and coffins, jewellery, and a strike-a- 
light, were not the subject of interest and discussion whatsoever. They were not included with the reburial but remain in various museum collections. Why not add these things to the reburial? They surely belonged to the dead and their graves? Given this discussion about neglecting the individual aspects of the dead, it may be difficult to comprehend how the identity and the spiritual and physical dignity of the dead were re-established.

\section{Displacement of Care}

The Sámi politician and physician Ole Mathis Hætta criticized the reburial in Njauddâm/Neiden as an embellishment of history. Consequently, he argued for the preservation of the human remains in museums as a testimony to future generations about what happened in history (see Svestad 2013a, 201). I do not claim that Sámi (or indigenous) decision-making is simple, but in all the cases discussed in this article, the new features or adjustments made may be perceived as embellishments of history in a similar way. While the symbolic, mythical and political aspects related to past wrongs and loss of history and identity seem to be of primary significance, the remains themselves seem to be offered a disinterest or displacement of care. There is an irony involved here. While repatriation is launched as a matter of unifying a link that has been broken between the living and the dead, the objects and human remains are separated without a problem. While repatriation relates to the acknowledgement and re-establishment of cultural identity, the identity of the dead created through objects and things is violated (human remains buried without their non-human counterparts). Furthermore, new things and features (new coffins and pulkas, reindeer pelt, burial mound, etc.) are introduced without a problem. The same goes for authenticity. Thus, the remains of the dead turn out to be more of a political fact than an ethical concern (cf. Domanska 2006, 344). 
The above aspects are evident in the Sierkejukke/Risbäcken case, for which the reburial continues to be named Soejvengeelle (Heinerud 2002, 19; Stångberg 2005; Nordberg and Fossum 2011, 209), even though this man was not the buried individual. In other words, prevalence is given to politics and mythopoeia at the expense of the actual affiliation and identity of the remains. I do not repudiate political aspects of repatriation and reburials. However, in the Njauddâm/Neiden reburial, the displacement of care appears more importunate, as briefly described above (for further discussion, see Svestad 2013a). This point was further emphasized in the way the site went through what might be perceived as a cleansing process before reburial. After excavation of the remains in Njauddâm/Neiden in 1915 , the ground, which for the most part was an unknown cemetery at the time, continued to be in use as farmland. After WWII, a farmhouse and barn were erected, and in the 1950s a campground was established with small cabins built on the outskirts of the property. Before reburial, all these buildings, except the house and the old hut (house) of the aforementioned Ondre Jacobovitsj, were demolished and removed to make a proper reburial site. This may be considered necessary in the construction of a site of symbolic and political significance, but at the same time it was cleansed of constructions that clearly belonged to the site's history. One may argue that even though these buildings belonged to the site's history, they do not belong to a cemetery. However, they clearly did for many decades, as did the various exploitations of the earth above the forgotten cemetery. In any case, the removal of certain buildings and the reconstruction of the site adds to the most prominent estrangement of the reburial in the shape of a "Viking Age" burial mound; a phenomenon which is nothing but alien to the mortuary practices of the Skolt Sámi. The reason for this configuration is unclear but did not seem to have been an issue of discussion, either among those in charge of the reburial or Sámi in favour of it (Svestad 2013a, 198-202; Honna Havas, personal communication, March 17, 
2017). This process emphasizes the conventional understanding that only certain things and aspects are given ethical concern in repatriation and reburial.

The above perspective may be seen in relation to a discussion in contemporary archaeology and critical heritage studies about how bad matter, matter out of place, and awkward or abject things are estranged from us (see, e.g. Graves-Brown 2011; Olsen et al. 2012; Pétursdóttir 2013; Olsen and Pétursdóttir 2016). Drawing on Mary Douglas's studies of purity and impurity, Paul Graves-Brown argues that "cleanliness and purity are often equated with order, whereas dirt, waste and decay are symbolically and physically excluded" (GravesBrown 2011, 136). Similar conditions for inclusion and exclusion seem to apply to the Njauddâm/Neiden reburial and the other burial/reburial cases. To create a site of symbolic purity, the campground, barn, and cabins in Njauddâm/Neiden were considered bad matter, or dirt, and had to be removed. The human remains, which manifested decay in their fragmented existence, were symbolically restored by placing the remains of each individual in identical new coffins in linear rows in the burial mound. In this way, unity, identity, and equality were signified. In comparison, the non-human remains, including fragments of coffins, iron nails, and other objects, were treated as bad matter and excluded from the whole repatriation. On the other hand, new things such as coffins were considered good matter, and so was the construction of "a really out of place" burial mound, which appears as an infringement of the remains themselves with regards to Skolt Sámi burial customs. In comparison with the Sierkejukke/Risbäcken case, it appears as yet another infringement that the reburial of the individual did not pay more attention to the human remains or remaining things, but instead reconstructed the grave and some of the remains to a more complete and "authentic" state. However, in opposition yet again, one may point to the irrelevance of archaeological correctness, given the importance of the ritual and the definition of "Sáminess" through the elements included. 
Notwithstanding, the handling of the Njauddâm/Neiden and Sierkejukke/Risbäcken reburials gives the impression of being in situ conservations and renovations typical of modern European cultural heritage management (cf. Brattli 2009, 27, 33). The significance is the presence of human remains on their original burial ground, not their content, individuality, and non-human counterparts. At the same time, this praxis demonstrates affiliation with the understanding of a recent trend in heritage studies. According to Póra Pétursdóttir (2013, 32-33) this trend, which is most prominently represented by scholars such as Laurajane Smith and Emma Waterton (Smith 2006; Smith and Akagawa 2009; Waterton and Smith 2009), claims the essence of all heritage to be intangible, and consequently there is no such thing as heritage. In Pétursdóttir's critical perspective, Smith perceives heritage "as a mentality, an experience or an act of remembering that engages with the present" (Pétursdóttir 2013, 35, cf. Smith 2006), and that the things or sites themselves are not imperative to this process. In a similar way, Sámi repatriation and reburial stand out as a mental act in which human remains are not imperative qua remains, but only as means of rituals and making up for past wrongs and loss of identity. Its overt lack of interest in non-human remains underlines the intangible, and rather anti-material, significance of this praxis. Thus, in its ardent ambition to make penitential exercises for colonialism and the consequences of history, the dead and their remains are suspended and instead re-established with the beliefs, meanings and moral attitudes of the living.

A brief reference to some aspects of Michel Foucault's far-reaching analysis of the ontology of the modern self may shed some light on this aspect. In the article "What Is Enlightenment?" Foucault $(1991,39)$ refers to the Greek ethos as a point of departure. This concept is perceived as a historic-critical attitude of analysing and reflecting upon limits of the self. This process implies inquiries of how we are constituted as subjects of our own knowledge, subjects who exercise or submit to power relations, and subjects of our own moral 
actions. Foucault states: "These inquiries have their theoretical coherence in the definition of the historically unique forms in which the generalities of our relations to things, to others, to ourselves, have been problematized" (Foucault 1991, 50). Inspired by this view, one may say that the objective of this article constitutes a reflection upon the limits of the living; more precisely, the limits between the living and the dead and their remains. One may thus ask a variety of questions. How is reburial related to the knowledge and moral values of living individuals? How is reburial politicized as acts of power? How do we reflect on what is historically unique, that is, what is repatriated in repatriations and what is buried in reburial? With reference to the cases discussed, one may answer that it appears the dead are not accepted as dead. Instead, they are recreated in the image of modern individuals, and then given a new and "proper" burial - to put a "proper" end to them. In this way, repatriation and reburial seem to have turned into a cleansing trope in which the dead have been "indigenized" through contemporary projections and cultural norms at the expense of the human and nonhuman remains themselves. What is historically unique is thus not contemplated in terms of human and non-human remains qua remains. The small fragments of bones and birch bark, rust and dust, severely decomposed and brought to their finitude of existence, are what are historically unique. Are these not the very remains of a past in the present, which should be made the subject of ethical concerns?

Grounded on the reflections above, the concept of human death and dignity in Sámi repatriation seems to reflect an essentially modern, anthropocentric structure of valuing that excludes the existence of things and what might be subject to ethical considerations. Although the exclusion of non-human remains may not always be a result of lack of interest from Sámi communities, but rather due to the opposition from museums, archaeologists and researchers, the interesting question is, as Tim Flohr Sørensen remarks in his discussion on archaeological ethics, "where we draw the line between those phenomena that are treated as if they can be 
subject to ethical claims and those that cannot" (Sørensen 2013, 14; cf. Olsen et al. 2012, 202; Svestad 2013a, 214). Sørensen holds "that we have a responsibility for being susceptible to the possibility of decay and disappearance as positive qualities of an object, place or practice" (Sørensen 2013, 14). In comparison, the estrangements of the Njauddâm/Neiden reburial, for instance, subsumes to almost the opposite. The core question remains: How are these fragile human and non-human remains cared for? Are they acknowledged in their fragmented existence? Do they represent something other than present self-understanding and identity?

\section{Remains Out of Place}

So, how should reburial be carried out? In what way should the remains be given a careful reburial? Take, for instance, the burial mentioned at the beginning of this paper: the repatriation of the skulls of Somby and Hætta. These remains were allegedly buried in the same place as their bodies according to tradition, but as mentioned in the introduction, this issue was not confirmed. However, a confirmation might have been achieved through an archaeological uncovering of the headless skeletons and joining of the skulls with the remains in Somby and Hætta's grave without adding things that did not belong there, such as the new miniature "pulkas". This may, of course, be a difficult task for which a positive result could not be predicted, but from the perspective of thing theory, one might perceive this approach to be more consistent with a caring for the dead and the remains themselves.

In the Sierkejukke/Risbäcken reburial, a similar approach may be suggested.

Knowledge about the burial was disclosed in the Manker investigation and the reinvestigation. The remains may, thus, have been brought back and placed in the grave according to documentation. However, the grave had been disturbed several times before Manker's investigation, which made an accurate repatriation or in situ conservation highly problematic. Nevertheless, the disturbances may be perceived as certain "palimpsests" of the 
ancestor's remains and considered part of the decaying process, which in turn challenge the very existence of remains and the concept of how remaining things remain.

In the case of Gamla Kyrknäset, Jaamišsuálui/Vanhahautuumaasaari, and Njauddâm/Neiden, a similar approach as above may be suggested, but the obscurity and obvious lack of knowledge of the remains in question make this a far more complicated act. In Njauddâm/Neiden, for instance, it was impossible to repatriate the human remains to their original graves, with the partial exception of one individual (Svestad 2013a, 211). From this perspective, it is easy to understand the local Sámi in the case of Gamla Kyrknäset, who originally opposed archaeological excavation and instead wanted the cemetery at Vilasund to be undisturbed and subjugated by water.

Upon reflection of the collecting and emptying of graves of human and other remains that created the premises of reburials in question, they seem to represent irreparable acts in which the original context and location of graves were corrupted, constituting what appears to be inevitable obstacles. These obstacles impose limitations on the repatriation issue, leaving human and non-human remains in what may be perceived as an everlasting out-of-place context. Bringing things out of the ground inevitably makes them infinitely liminal. Taking these obstacles seriously makes the idea of re-establishing unity, identity, and spiritual and physical dignity in reburial appear illusive (Svestad 2013a, 214; see also Nilsson Stutz 2007/2008). Thus, if the purpose of reburial is to put remains to political use and symbolically pay for the consequences of history, other alternatives might be suggested. Take, for instance, the skulls of Somby and Hætta. As manifestations of what happened in history, they may as well be exposed in the church rather than buried somewhat accidentally in the churchyard. This may, perhaps, be considered irreverent according to existing practice. But to push things to extremes, it would manifest the uniqueness of history - the killings and oppression, the execution and abduction - in a more powerful, present and thingly way. However, given the 
murders of which Somby and Hætta were convicted and executed, and the ethno-political background for events, their skulls do not make present what happened. Instead, they make present something that we cannot get rid of, such as mysteries or ghosts beyond final comprehension, which are valuable and of ethical concern. To paraphrase Domanska (2006, 346), they become the presence of the non-absent dead. By this emphasis, we turn to that which "is somehow still present, that will not go away or, rather, that of which we cannot rid ourselves" (Domanska 2006, 346) instead of a desire to represent the dead.

A somewhat similar view is presented by John Harries (also referring to Domanska) in his analysis of the skulls of Nonosabasut and Demasduit from the extinct native Beothuk of Newfoundland. Their skulls were taken from their graves near Red Indian Lake and brought to the National Museum of Scotland in Edinburgh in the late 1820s. In search of the presence of Nonosabatsut and Demasduit in communion with their remains, Harries concluded that "it is precisely in their insufficient and excessive quality of 'thingness' that their skulls possess the capacity to both animate and unsettle our relationship to the past" (Harries 2010, 419). Similarly, it is the thingness of Somby's and Hætta's skulls that make the past both present and absent. Thus, it is not evident that burial (or reburial) is the right thing to do in repatriation considering caring for the remains themselves. It may rather be the possibility of exposure, which makes the remains of Somby and Hætta, or other individuals, not "so easily controlled or subject to a finite interpretation" (Domanska 2006, 346), contrary to the burial/reburials in question.

The arguments above point to the significance of archaeology, given that archaeology is the discipline per se in caring for and elucidating things, as eloquently stated by Laurent Olivier: "Thus, no lines can be drawn between what belongs to the province of archaeology and what does not. Everything is archaeological, even the near past, even the present moment in which we now find ourselves ... the past is the materiality of the present" (Olivier 2013, 
124). As demonstrated through this article, archaeological knowledge can contribute to issues related to determining and debating identity, authenticity, in situ conservation and so forth, and thus extend ethical concern and, importantly, discussion, to the process of reburial. What is essential is, in agreement with archaeologists such as Alfredo Gonzáles-Ruibal, the manifestation of things, facing "the devastation and pain brought about by failed modernities" (Gonzáles-Ruibal 2008, 251). This implies a rhetoric not based on completeness but on the acceptance of what Gonzáles-Ruibal (with reference to Gavin Lucas 2005) characterize as "the inherently partial, fragmentary, and therefore uncanny nature of the archaeological record" (Gonzáles-Ruibal 2008, 251). This condition, which places ethos in terms of a caring attitude towards remaining things at the centre of archaeological revelation, signifies the banal fact that the very remains of the dead constitute the inevitable precondition for repatriation and reburial, and therefore should be of primary ethical concern

Given these premises, a reburial somewhat accidentally in the ground, modified, and altered according to present convenience and politics, does not present itself as the obvious ethical solution in caring for remains, even though our needs as intellectuals are not the only consideration. Still, museums, or other preservation facilities, may seem more suitable to their primary task of safekeeping, as a matter of taking care of what happened in history and testimony to future generations. The Skolt Sámi Museum in Njauddâm/Neiden (Norway), the Siida Sámi Museum at Lake Aanaar/Inari (Finland), and the Ájtte - Swedish Mountain and Sámi Museum in Dálvvadis/Jokkmokk (Sweden) are well suited for such tasks, of which the latter two are already repositories for human remains collected from Sámi graves in the nineteenth and/or early twentieth century. At the same time, this perspective implies acknowledgement of ethical issues related to the use of human and non-human remains in museums, although this issue is not in focus here. 
Much could be said about museums and their colonial history, but all things considered, it may seem difficult to suggest a more suitable place for the safekeeping of remains. This premise contradicts the above argument of the decaying process of remains as an inevitable aspect of death and caring for the dead. However, as indicated, bringing remains out of the ground is an irreversible act that takes things out of time and place and brings their process of decay to an end. Given these conditions, which makes repatriation to their original grave illusive, are analogous to the irreversible consequences of archaeological excavation. Thus, the human and non-human remains seem better off preserved in museums as tangible proofs of history and past wrongs. The emphasis here is not about research on these remains or in what way human and non-human remains are usable, but that they are the source of their own being, which should be made the subject of ethical concern.

\section{Conclusion}

In the seminal work on postcolonialism and decolonization by Frantz Fanon, The Wretched of the Earth ([1963] 1977), crucial aspects of colonization are defined along with how the history of the colonized became a silenced and devaluated topic of colonialist legitimacy. This silencing of, and distorting approach to, colonized people is still present in various parts of the world, including Fennoscandia, although to a lesser extent. With regard to the Sámi and their history, it started rather optimistically in the beginning of the 1800 s, but by the end the century and before WWII, Sámi history was almost a contradiction in terms. Their past was mostly turned into an ethnographic and physical anthropological study of the relics of a people on the verge of extinction (e.g. Svestad 1995; Schanche 2000; Hesjedal 2001). With minor exceptions, Sámi history did not become a significant topic of archaeological and historical research until the 1970s. Today, Sámi history is, in general, not devalued or ignored, although its time-depth, character and distribution are discussed or occasionally 
contested (e.g. Wallerström 2006; Hansen and Olsen 2014; Hood 2015; Olsen 2016).

Paradoxically, the Sámi repatriation issue seems to constitute a field of its own, in which the dialectics announced by Fanon are not particularly present. Sámi past is instead perceived as something fixed, an a priori that facilitates the reburial estrangements of history and the things themselves, which have been demonstrated and discussed in this article. In this perspective, Sámi reburial marks itself almost as a quick fix, while the dead, their human and, in particular, non-human remains, are treated in a rather disinterested fashion. To put it bluntly, one may question from the state of things how a symbolic return to a site of which estrangements have to be made for the sake of present convenience and the moral and political strategies of the living is more ethical than keeping the out-of-place remains, both human and non-human, in museums.

Sámi readers might perhaps find this deconstruction of their reburial ceremonies as an example of colonialism - in other words archaeologists/scientists telling indigenous people how they should act. This is not my intent. As an archaeologist, I can only offer my reflections and perspectives. I fully acknowledge the indigenous or Sámi right to manage their own cultural heritage, and, as stated, I do not contest the sensitivity and complexity of the matter of repatriation, which I also acknowledge easily conflicts with the perspectives forwarded in this paper. Nor do I contest that there is a profound emotional process in Sámi and in other indigenous communities in recognizing the remains as humans and respecting them deeply, or that reburials are experienced as healing old wounds or justified penitential exercises. My intention is not to be insensitive towards Sámi, as well as other indigenous peoples, who still experience degradation and loss of history, language and rights as the result of previous and ongoing colonialism. However, the effects of colonialism are wide-ranging and of subtle complexity, yet to be fully understood, which makes the quest for cultural and colonial emancipation an intricate and somewhat contradictory matter. Furthermore, I 
acknowledge some reburial cases are not that easy, and I do not deny that reburial may be the only thing to do, or that "quick fixes" are right or just.

Condemning my perspectives as colonialist might be an effective mode of stigmatization. Nevertheless, my perspectives are of reflexive and dialogical character. The intention has been to ask questions, and to emphasize caring - as something different from respect - for human and non-human remains. I think caring for (caring about, providing for, taking care of) these remains is largely ignored and not ascribed any ethical concern in Sámi repatriation and reburial (or in international debates for that matter). In this way, the goal is to open the way for alternative perspectives on the ethics of dealing with the fallacies of colonialist collecting of Sámi human and non-human remains. Giving back the bones and their associated non-human remains seems to be an ethical response, but reburial does not always present itself as the obvious ethical solution.

\section{Acknowledgements}

Thanks to Póra Pétursdóttir for insightful comments and Johan Eilertsen Arntzen for producing the map illustration. Thanks also to the referees, Liv Nilsson-Stutz and two anonymous reviewers, for raising important questions and comments that have improved this article, although it should be admitted that some remarks are clearly incommensurable with my own perspectives.

\section{References}

Aarseth, Bjørn. 2000. "Hodeskaller og hodeløs forskning." Hammarn 7 (6): 12-15.

Aikio, Matti. 1914. Polarlandsbreve og andre. Kristiania: Helge Erichsen Forlag. 
Andresen, Astri. 2007. "In the Wake of the Kautokeino Event: Changing Perceptions of Insanity and the Sámi 1852-1965.” Acta Borealia 24 (2): 130-142. doi:

$10.1080 / 08003830701661746$.

Aronsson, Kjell-Åke. 2013. "Research on Human Remains of Indigenous People: Reflections from an Archaeological Perspective (with an example from Rounala)." In More Than Just Bones - Ethics and Research on Human Remains, edited by Hallvard Fossheim, 65-80. Oslo: The Norwegian National Research Ethics Committees.

Arponen, Aki. 1993. "Inarin hautuumaasaaret.” Metsähallituksen luonnonsuojelujukaisuja Sarja A, no. 16. Vantaa: Metsähallitus.

Assmundsson, Mikael. 2016. “25 kranier skal återbegravas i Lycksele.” SVT Nyheter, March 11. http://www.svt.se/nyheter/lokalt/vasterbotten/25-kranier-ska-aterbegravas-i-lycksele [Accessed March 17, 2017]

Ballari, Aslak. 2013. "Dømt til døden for drap - kan bli halehelt.” NRK Nyheter, November 26. https://www.nrk.no/troms/drapsdomt-kan-bli-halehelt-1.11379730 [Accessed October 3, 2017]

Benso, Siliva. 2000. The Face of Things: A Different Side of Ethics. Albany: State University of New York Press. 
Bjørklund, Ivar. 1992. “The Anatomy of a Millennarian Movement: Some Organizational Conditions for the Sami Revolt in Guovdageaidnu in 1852." Acta Borealia 9 (2): 37-46. doi: $10.1080 / 08003839208580415$.

Bjørklund, Ivar. 2008. “Kautokeino 1852.” Dagbladet, January 26.

https://www.dagbladet.no/kultur/kautokeino-1852/66432771 [Accessed October 3, 2017]

Brattli, Terje. 2009. "Managing the Archaeological World Cultural Heritage: Consensus or Rhetoric?” Norwegian Archaeological Review 42 (1): 24-39. doi:

$10.1080 / 00293650902904505$.

Brown, Bill. 2001. "Thing Theory." Critical Inquiry 28 (1): 1-22.

Bruchac, Margaret M., Siobhan M. Hart, and Martin H. Wobst, eds. 2010. Indigenous Archaeologies: A Reader on Decolonization. Walnut Creek, CA: Left Coast Press.

Bull, Kirsti Strøm. 1996. “Da forskerne tapte hodet.” Kritisk juss 23 (4): 274-279.

Christensen, Cato. 2012. "Reclaiming the Past: On the History-making Significance of the Sámi Film TheKautokeinoRebellion.” Acta Borealia 29 (1): 56-76. doi:

10.1080/08003831.2012.678720.

Colwell-Chanthaphonh, Chip, Julie Hollowell, and Dru McGill. 2008. Ethics in Action: Case Studies in Archaeological Dilemmas. Washington D.C.: Society for American Archaeology. 
Domanska, Ewa. 2006. “The Material Presence of the Past.” History and Theory 45

(October): 337-348. doi: 10.1111/j.1468-2303.2006.00369.x.

Drivenes, Einar-Arne, and Regnor Jernsletten. 1994. "Det gjenstridige Nord-Norge: Religiøs, politisk og etnisk mobilisering 1850-1990.” In Nordnorsk kulturhistorie: Det gjenstridige landet, vol. 1, edited by Einar-Arne Drivenes, Marit Anne Hauan, and Helge A. Wold, 210-281. Oslo: Gyldendal Norsk Forlag.

Falck, Torvald, and Marianne Skandfer. 2004. "Sámi Cultural Heritage in Norway: Between Politics of Local Knowledge and the Power of the State.” In Northern Ethnographic Landscapes. Perspectives from Cercumpolar Nations, edited by Igor Krupnik, Rachel Manson, and Tonia W. Horton, 358-378. Washington D.C.: Arctic Studies Center, National Museum of Natural History, Smithsonian Institution/The National Park Service.

Fanon, Frantz. (1963) 1977. The Wretched of the Earth. An Evergreen Black Cat edition. Preface by J.-P. Sartre, trans. C. Farrington. New York: Grove Press.

Ferris, Neal, and John R. Welsh. 2015. "New Worlds: Ethics in Contemporary North American Archaeological Practice.” In Ethics and Archaeological Praxis, edited by Cristóbal Gnecco, and Dorothy Lippert, 69-92. Ethical Archaeologies: The Politics of Social Justice 1. New York: Springer.

Fforde, Cressida, Jane Hubert, and Paul Turnbull, eds. 2002. The Dead and their Possessions: Repatriation in Principle, Policy and Practice. London: Routledge. 
Fossheim, Hallvard, ed. 2013. More Than Just Bones - Ethics and Research on Human Remains. Oslo: The Norwegian National Research Ethics Committees.

Foucault, Michel. 1991. "What Is Enlightenment?” In The Foucault Reader: An Introduction to Foucault's Thought, edited by Paul Rabinow, 32-50. London: Penguin Books.

Gonzáles-Ruibal, Alfredo. 2008. "Time to Destroy: An Archaeology of Supermodernity." Current Anthropology 49 (2): 247-279. doi: 10.1086/526099.

Gonzáles-Ruibal, Alfredo. 2018. "Ethics of Archaeology.” Annual Review of Anthropology 47: 345-360. doi: 10.1146/annurev-anthro-02317045825.

Goldstein, Lynne. 2013. "Reburial Ethics: Svestad's Analysis of the Neiden Sámi Case." Norwegian Archaeological Review 46 (2): 225-227. doi: 10.1080/00293652.2013.839580.

Grahn, Andreas. 2012. "Tärna kyrka, Storumans kommun, Västerbottens län. Kulturhistoriska värdebeskrivningar över kyrkomiljöerna i Västerbottens län.” Report. Västerbotten: Länsstyrelsen Västerbotten.

Graves-Brown, Paul. 2011. "Touching from a distance: Alienation, Abjection, Estrangement and Archaeology." Norwegian Archaeological Review 44 (2): 131-144. doi:

$10.1080 / 00293652.2011 .629808$.

Hallström, Gustaf. 1935. “Ur fjälltrakternas fornhistoria.” Samefolkets Egen Tidning 17 (2): $16-18$. 
Hamilakis, Yannis, and Philip Duke, eds. 2007. Archaeology and Capitalism: From Ethics to Politics. One World Archaeology 54. London: Routledge.

Hansen, Lars Ivar, and Bjørnar Olsen. 2014. Hunters in Transition: An Outline of Early Sámi History. The Northern World - North Europe and the Baltic ca. 400-1700 AD. Peoples, Economic and Cultures, vol. 63. Leiden: Brill.

Harlin, Eeva-Kristiina. 2008a. "Repatriation as Knowledge Sharing - Returning the Sámi Cultural Heritage.” In Utimut. Past Heritage - Future Partnerships. Discussions on Repatriation in the 21st Century, edited by Mille Gabriel, and Jens Dahl, 192-201. Copenhagen: The Greenland National Museum \& Archives/International Work Group for Indigenous Affairs.

Harlin, Eeva-Kristiina. 2008b. Recalling Ancestral Voices - Repatriation of Sámi Cultural Heritage. Projektets Interreg IIIA Slutrapport. Inari: Siida Sámi Museum.

Harries, John. 2010. “Of Bleeding Skulls and the Postcolonial Uncanny: Bones and the Presence of Nonosabasut and Demasduit. " Journal of Material Culture 15 (4): 403-421. doi: $10.1177 / 1359183510382962$.

Harrison, Rodney. 2012. Heritage: Critical Approaches. London: Routledge. 
Hedlund, Therese. 2011. Osteologisk undersökning av samiskt skelett (JLM 280 18) från Gransjö vid Ohredahke sameby, Frostviken socken, Jämtland. Reports in Osteology 5. Lund: Lunds University.

Heinerud, Jans. 2002/2004. Soejvengelle. Rapport över arkeologisk undersökning av samisk grav samt återbegravning av skelett, RAÄ 195:1, Tärna socken, Storumans kommun, Västerbottens län. Archaeological report. Umeå: Västerbottens museum.

Heinerud, Jans. 2011. “The Repatriation of Soejvengelle.” In Archaeology of Indigenous Peoples in the North: Proceedings from a Workshop held in Vuollerim 6000 år, 3-4 December 2005, edited by Anders Olofsson, 73-80. Archaeology and Environment 27. Umeå: Umeå University.

Hesjedal, Anders. 2001. Samisk forhistorie i norsk arkeologi 1900-2000. PhD Thesis. Stensilserie B no. 63. Tromsø: University of Tromsø.

Hirsti, Reidar. 1994. Sameopprøret. Oslo: Gyldendal Norsk Forlag.

Hodder, Ian. 2012. Entangled: An Archaeology of the Relationships between Humans and Things. Chichester: Wiley-Blackwell.

Holand, Ingegerd. 2004. "Managing the Sámi Cultural Heritage in Norway: The Legal Landscape.” In Northern Ethnographic Landscapes. Perspectives from Cercumpolar Nations edited by Igor Krupnik, Rachel Manson, and Tonia W. Horton, 81-104. Washington D.C.: 
Arctic Studies Center, National Museum of Natural History, Smithsonian Institution/The National Park Service.

Holand, Ingegerd, and Ingrid Sommerseth. 2013. "Ethical Issues in the Semi-Darkness: Skeletal Remains and Sámi Graves in Arctic Norway.” In More Than Just Bones - Ethics and Research on Human Remains, edited by Hallvard Fossheim, 21-47. Oslo: The Norwegian National Research Ethics Committees.

Holck, Per. 1990. Den fysiske antropologi i Norge. Oslo: Anatomisk Institutt, Universitetet i Oslo.

Hood, Bryan. 2015. "Framing Sámi Entanglement in Early Modern Colonial Processes: Ethnohistorical and Archaeological Perspectives from Interior North Norway." Arctic Anthropology 52 (2): 37-56. doi: 10.3368/aa.52.2.37.

Introna, Lucas D. 2009. "Ethics and the Speaking of Things." Theory, Culture \& Society 26 (4): 25-46. doi: 10.1177/0263276409104967.

Iregren, Elisabeth. 2002. “Hur bevara samernas biologiska historia?” In Vem äger kulturarvet? Anföranden vid konferens om återföringsfrågor vid Ajtte - Svenskt Fjäll- och Samemuseum 6-8 juni 2000. Duoddaris 20: 87-94. Jokkmokk: Ájtte - Svenskt Fjäll- och Samemuseum/Ájtte - Swedish Mountain and Sámi Museum.

Iregren, Elisabeth. 2010. "Vi behöver tydliga regler för bevaring/återbegravning av mänskliga lämningar.” Fornvännen, Journal of Swedish Antiquarian Research 105 (1): 54-60. 
Isaksson, Pekka. 2000. "Finsk fysisk antropologi, samerna och rasantropologins kris.” In Den komplexa kontinenten. Staterna på Nordkalotten och samerna i ett historiskt perspektiv, edited by Peter Sköld, and Patrik Lantto, 197-209. Umeå: Umeå University.

Itkonen, Toivo Immanuel. 1946. Heidnische Religion und späterer Aberglaube bei den finnischen Lappen. Suomalais-Ugrilaisen Seuran Toimituksia LXXXVII. Helsinki: Suomalais-Ugrilainen Seura.

Karlsen, Ola. 2014. "Krangler om skjebnen til 21 bortførte skjeletter.” ABC Nyheter, October 10. https://www.abcnyheter.no/nyheter/2014/10/26/209726/krangler-om-skjebnen-til-21bortfoerte-skjeletter [Accessed March 17, 2017].

Karlsson, Håkan, ed. 2004. Swedish Archaeologists on Ethics. Lindome: Bricoleur Press.

Karlsson, Håkan. 2013. “A New Ethical Path for Archaeology?” Norwegian Archaeological Review 46 (2): 227-230. doi: 10.1080/00293652.2013.839579.

Kemiläinen, Aira. 1998. Finns in the Shadow of the "Aryans": Race Theories and Racism. Studia Historia 59. Helsinki: Suomen Historiallinen Seura/Finnish Historical Society.

Kristiansen, Idar. 1970. Korstog mot Kautokeino. Oslo: Grøndahl.

Latour, Bruno. 1999. Pandoras's Hope. Essays on the Reality of Science Studies. Cambridge, MA: Harvard University Press. 
Lehtola, Veli-Pekka. 2005. “'The Right to One’s Own Past’. Sámi Cultural Heritage and Historical Awareness." In The North Calotte - Perspectives on the Histories and Cultures of Northernmost Europe, edited by Maria Lähteenmäki, and Päivi M. Pihlaja, 83-94. Helsinki: University of Helsinki.

Liedgren, Åsa. 2016. Silbojokk 2016. Arkeologisk räddningsundersökning av kyrka och kyrkogård inom Rä̈ Arjeplog 368:1, Arjeplogs KRÖLM 3:1, Arjeplogs kommun, Lapplands landskap, Norrbottens län. Rapport 12. Luleå: Norrbottens museum.

Lucas, Gavin. 2005. The Archaeology of Time. London: Routledge.

Lynott, Mark J., and Alison Wylie. 2000. Ethics in American Archaeology. $2^{\text {nd }}$ rev. ed. Washington, D.C.: Society for American Archaeology.

Manker, Ernst. 1961. Lappmarksgravar. Acta Lapponica XIII. Stockholm: Almqvist \& Wiksell.

Masterton, Malin. 2010. Duties to Past Persons: Moral Standing and Posthumous Interests of Old Human Remains. PhD Thesis. Acta Universitatis Upsaliensis. Uppsala: University of Uppsala.

Meschke, Christian. 1977. Early Norrland Sites on the Umeälven: A Study of a CulturalHistorical Survey. Early Norrland 3. Stockholm: Kungl. Vitterhets Historie og Antikvitets Akademien. 
Meskell, Lynn. 2010. "Human Rights and Heritage Ethics.” Anthropological Quarterly 83 (4): 839-859. doi: 10.1353/anq.2010.0023.

Meskell, Lynn. 2012. “The Social Life of Heritage.” In Archaeological Theory Today, second edition, edited by Ian Hodder, 229-250. Cambridge: Polity.

Mihesuah, Devon A., ed. 2000. Repatriation Reader: Who Owns American Indian Remains? Lincoln, NE: University of Nebraska Press.

Minde, Henry. 2001. "Sami Land Rights in Norway: A Test Case for Indigenous Peoples." International Journal on Minority and Group Rights 8: 107-125. doi: $10.1163 / 15718110120908367$.

Minde, Henry. 2003. "The Challenge of Indigenism: The Struggle for Sami Land Rights and Self-Government in Norway 1960-1990." In Indigenous Peoples, edited by Svein Jentoft, Henry Minde, and Ragnar Nilsen, 75-106. Delft: Eburon.

Mulk, Inga-Maria. 2009. “Conflicts over the Repatriation of Sámi Cultural Heritage in Sweden.” Acta Borealia 26 (2): 194-215. doi: 10.1080/08003830903372092.

Mundal, Else. 2012. “Kong Håkon Magnussons rettarbot for Hålogaland av 1313 og andre kjelder til kristninga av samane i mellomalderen." In Fjold veit hon fraeða: Utvalde arbeid av Else Mundal, edited by Odd Einar Haugen, Bernt Øyvind Thorvaldsen, and Jonas Wellendorf, 339-358. Oslo: Novus forlag. 
Näätänen, Esko K. 1936. Über de Anthropologie der Lappen in Suomi. Helsinki: Sana.

Nilsson Stutz, Liv. 2007/2008. “Archaeology, Identity, and the Right to Culture:

Anthropological Perspectives on Repatriation." Current Swedish Archaeology 15-16: $157-172$.

Nilsson Stutz, Liv. 2008. "Caught in the Middle - An Archaeological Perspective on Repatriation and Reburial." In Utimut. Past Heritage - Future Partnerships. Discussions on Repatriation in the 21st Century, edited by Mille Gabriel, and Jens Dahl, 84-99. Copenhagen: The Greenland National Museum \& Archives/International Work Group for Indigenous Affairs.

Nilsson Stutz, Liv. 2013. "Claims to the Past. A Critical View of the Arguments Driving Repatriation of Cultural Heritage and Their Role in Contemporary Identity Politics." Journal of Intervention and Statebuilding 7 (2): 170-195. doi: 10.1080/17502977.2012.714243.

Nordberg, Erik, and Birgitta Fossum. 2011. "Traditional Knowledge and Cultural Landscape.” Dieđut 1: 193-223.

Ojala, Carl-Gösta. 2009. Sámi Prehistories: The Politics of Archaeology and Identity of Northernmost Europe. Occasional Papers in Archaeology 47. Uppsala: University of Uppsala. 
Ojala, Carl-Gösta. 2016. “Svenska kyrkan och samiska mänskliga kvarlevor.” In De historiska relationerna mellan Svenska kyrkan och samerna. En vetenskaplig antologi, vol. 2., edited by Lindmark, Daniel, and Olle Sundström, 993-1028. Skellefteå: Artos \& Norma.

Olivier, Laurent. 2013. “The Business of Archaeology in the Present.” In Reclaiming Archaeology: Beyond the Tropes of Modernity, edited by Alfredo González-Ruibal, 117-129. London: Routledge.

Olsen, Bjørnar. 2003. "Material Culture After Text: Re-Membering Things." Norwegian Archaeological Review 36 (2): 87-104.

Olsen, Bjørnar. 2010. In Defense of Things: Archaeology and the Ontology of Objects. Lanham, MD: AltaMira Press.

Olsen, Bjørnar. 2016. "Sámi Archaeology, Postcolonial Theory, and Criticism." Fennoscandia Archaeologica 23: 215-229.

Olsen, Bjørnar and Póra Pétursdóttir. 2016. "Unruly Heritage: Tracing Legacies in the Anthropocene.” Arkceologisk Forum 35: 38-45.

Olsen, Bjørnar, Michael Shanks, Timothy Webmoor, and Christopher Witmore. 2012. Archaeology: The Discipline of Things. Berkeley: University of California Press. 
Ovsiannikov, Oleg V. 1993. The Arctic of Russia in the Middle Ages: Recent Archaeological Discoveries and the Ancient Trade Route along the Arctic Coast. Tromsø: University of Tromsø.

Paasche, Knut, and Immo Trinks. 2010. Georadarundersøkelser av gravplass i Skoltebyen Neiden, Finnmark: Arkeologisk undersøkelse. Oslo: NIKU report, 33/RAÄ UV Teknik, report.

Paulsen, Simon Piera, and Sander Andersen. 2014. "Denne hodeskallen kan endre historien." NRK Sápmi, June 24. https://www.nrk.no/sapmi/_-dette-funnet-endrer-historien-1.11795327 [Accessed March 17, 2017].

Pettersson, Olof. 1957. Jabmek and Jabmeaimo. A Comparative Study of the Dead and the Realm of the Dead in Lappish Religion. Acta Universitatis Lundensis, Nova Series 52 (6). Lund: C.W.K. Gleerup.

Pétursdóttir, Póra. 2012. "Small Things Forgotten Now Included, or What Else Do Things Deserve?” International Journal of Historical Archaeology 16 (3): 577-603. doi: 10.1007/s10761-012-0191-0.

Pétursdóttir, Póra. 2013. "Concrete Matters: Ruins of Modernity and the Things Called Heritage.” Journal of Social Archaeology 13 (1): 31-53. doi: 10.1177/ 1469605312456342. 
Pétursdóttir, Póra, and Bjørnar Olsen. 2017. "Theory Adrift: The Matter of Archaeological Theorizing." Journal of Social Archaeology 18 (1): 97-117. doi:

$10.1177 \% 2 \mathrm{~F} 1469605317737426$.

Pickering, Michael. 2011. "Dance Through the Minefield. The Development of Practical Ethics for Repatriation.” In Routledge Companion to Museum Ethics: Redefining Ethics for the Twenty-First Century Museum, edited by Janet Marstine, 256-274. New York: Routledge.

Preda, Alex. 1999. "The Turn to Things: Arguments for a Sociological Theory of Things." The Sociological Quarterly 40 (2): 347-366.

Rasmussen, Siv. 2016. “Samisk integrering i norsk og svensk kirke i tidlig nytid - En komparasjon mellom Finnmark og Torne lappmark.” Ph.D. diss., UiT - The Arctic University of Norway.

Scarre, Chris, and Geoffrey Scarre, eds. 2006. The Ethics of Archaeology: Philosophical Perspectives on Archaeological Practice. Cambridge: Cambridge University Press.

Schanche, Audhild. 2000. Graver i ur og berg: Samisk gravskikk og religion fra forhistorisk til nyere tid. Karasjok: Davvi Girji.

Schanche, Audhild. 2002a. Museer, gjenstander, rettigheter. In Vem äger kulturarvet? Anföranden vid konferens om återföringsfrågor vid Ajtte - Svenskt Fjäll- och Smemuseum, 6-8 juni 2000. Jokkmokk: Ájtte - Svenskt Fjäll- och Samemuseum, 29-33. 
Schanche, Audhild. 2002b. "Sami Skulls, Anthropological Race Research and the Repatriation Question in Norway." In The Dead and their Possessions: Repatriation in Principle, Policy and Practice, edited by Cressida Fforde, Jane Hubert, and Paul Turnbull, 47-58. London: Routledge.

Schanche, Audhild. 2002c. "Knoklenes verdi: Om forsking på og forvaltning av skjelettmateriale fra samiske graver.” Samisk forskning og forskningsetikk 2, 99-133. Oslo: Den nasjonale forskningsetiske komité for samfunnsvitenskap og humaniora.

Sellevold, Berit J. 2002. "Skeletal Remains of the Norwegian Saami." In The Dead and their Possessions: Repatriation in Principle, Policy and Practice, edited by Cressida Fforde, Jane Hubert, and Paul Turnbull, 59-62. London: Routledge.

Simma, Paul-Anders. 1999. “Giv os vore skeletter!” NCB Film. København: Det Danske Filminstitut.

Skjeggedal, Terje and Kjell Overvåg. 2017. “Cultural Heritage Management and Local Development in a South Sámi and Norse Mountainous Borderland.” Norsk Geografisk Tidsskrift - Norwegian Journal of Geography 71 (1): 30-45. doi: 10.1080/00291951.2017.1290674.

Skotnes, Vanja. 2016. "Nå skal 60-åringens hodeskalle fra 1600-tallet begraves.” iFinnmark, October 1. https://www.ifinnmark.no/kautokeino/nyheter/historie/na-skal-60-aringenshodeskalle-fra-1600-tallet-begraves/s/5-81-344917 [Accessed March 9, 2017]. 
Smith, Claire, and Martin H. Wobst, eds. 2005. Indigenous Archaeologies: Decolonizing Theory and Practice. One World Archaeology, 47. London: Routledge.

Smith, Laurajane. 2006. Uses of Heritage. London: Routledge.

Smith, Laurajane, and Natsuko Akagawa, eds. 2009. Intangible Heritage. Abingdon:

Routledge.

Smith, Linda Tuhiwai. 1999. Decolonizing Methodologies: Research and Indigenous Peoples. London: Zed Books.

Smith, Peter Lorenz. 1938. Kautokeino og Kautokeino-lappene: En historisk og ergologisk regionalstudie. Instituttet for sammenliknende kulturforskning. Serie B: Skrifter XXXIV. Oslo: H. Aschehoug (W. Nygaard).

Solli, Brit. 2011. "Some Reflections on Heritage and Archaeology in the Anthropocene." Norwegian Archaeological Review 44 (1): 40-88.

Steen, Adolf. 1965. Kautokeino-tragedien 1852, et justismord? Kristiansand.

Stångberg, Andreas. 2005. “Soejvengeelle: en samisk grav i Vapsten.” In Efter fornfädernas sed: Om samisk religion, edited by Åsa Virdi Kroik, 53-67. Göteborg: Boska. 
Sveriges Radio. 2011. "Hon begravs för andra gången.” Sameradioen \& SVT Sápmi, August 12. http://sverigesradio.se/sida/artikel.aspx?programid=2327\&artikel=4642654 [Accessed March 17, 2017].

Svestad, Asgeir. 1995. Oldsakenes orden: Om tilkomsten av arkeologi. Oslo: Universitetsforlaget.

Svestad, Asgeir. 2007. “'Folk er vanligvis ikke særlig villige til å snakke om de døde’ Synspunkter på materialitet og samisk gravskikk.” Arkeologi i Norr 10: 41-76.

Svestad, Asgeir. 2011. "The Impact of Materiality on Sámi Burial Customs and Religion.” Fennoscandia Archaeologica, 28: 39-56.

Svestad, Asgeir. 2013a. "What Happened in Neiden? On the Question of Reburial Ethics." Norwegian Archaeological Review 46 (2): 194-222. doi: 10.1080/00293652.2013.839575.

Svestad, Asgeir. 2013b. "Reply to Comments from Kjell-Åke Aronsson, Lynne Goldstein, Håkan Karlsson, Duncan Sayer and Larry J. Zimmerman.” Norwegian Archaeological Review 46 (2): 236-242. doi: 10.1080/00293652.2013.839582.

Svestad, Asgeir. 2017. "Svøpt i myra - Synspunkter på Skjoldehamnfunnets etniske og kulturelle tilknytning." Viking LXXX: 129-156. doi: 10.5617/viking.5476.

Svestad, Asgeir. 2018. "Entering Other Realms: Sámi Burials in Natural Rock Cavities and Caves in Northern Fenno-Scandinavia between 900 BC and AD 1700.” In Caves and Ritual 
in Medieval Europe, AD 500-1500, edited by Knut Andreas Bergsvik, and Marion Dowd, 13-31. Oxford: Oxbow.

Swindler, Nina, Kurt E. Dongoske, Roger Anyon, and Alan S. Downer, eds. 1997. Native Americans and Archaeologists: Stepping Stones to Common Ground. Walnut Creek, CA: AltaMira Press.

Sørensen, Tim Flohr. 2013. "We Have Never Been Latourian: Archaeological Ethics and the Posthuman Condition.” Norwegian Archaeological Review 46 (1): 1-18. doi:

10.1080/00293652.2013.779317.

Thomas, David Hurst. 2000. Skull Wars. Kennewick Man, Archaeology, and the Battle for Native American Identity. New York: Basic Books

Turi, Johan. 1911. Muittalus samid birra: En bog om Lappernes liv. Published with Danish translation by Emilie Demant. Organization and foreword by Hjalmar Lundbom. Third ed. Stockholm: Nordiska bokhandeln.

Vitelli, Karen D., and Chip Colwell-Chanthaphonh. 2006. Archaeological Ethics. Lanham: Altamira Press.

Wallerström, Thomas. 2006. Vilka var först? En nord-skandinavisk konflikt som historiskarkeologisk dilemma. Stockholm: Riksantikvarieämbetet. 
Waterton, Emma, and Laurajane Smith, eds. 2009. Taking Archaeology out of Heritage.

Newcastle upon Tyne: Cambridge Scholars Publishing.

Webmoor, Timothy, and Christopher L. Witmore. 2008. "Things are Us! A Commentary on Human/Things Relations under the Banner of a 'Social' Archaeology." Norwegian

Archaeological Review 41 (1): 53-70. doi: 10.1080/00293650701698423.

Ween, Gro B. 2012. "World Heritage and Indigenous Rights: Norwegian Examples.”

International Journal of Heritage Studies 18 (3): 257-270. doi:

$10.1080 / 13527258.2012 .663779$.

Wetlesen, Jacob. (1854) 1997. Letter from Vicar Jacob Wetlesen to Bishop Daniel Bremer Juell dated October 14, 1854. Dag og Tid, April 17, 1997.

http://old.dagogtid.no/arkiv/1997/16/kauto3.html [Accessed March 17, 2017].

Zachrisson, Inger. 1976. Lapps and Scandinavians. Archaeological Finds from Northern Sweden. Early Norrland 10. Stockholm: Kungl. Vitterhets Historie og Antikvitets Akademien.

Zimmerman, Larry J. 1989. "Made Radical by My Own: An Archaeologist Learns to Accept Reburial." In Conflict in the Archaeology of Living Traditions, edited by Robert Layton, 60-67. London: Unwin Hyman.

Zimmerman, Larry J. 2013. “'Beings Who Are', 'Beings Who Were', and the Neiden Reburial." Norwegian Archaeological Review 46 (2): 233-236. doi:

$10.1080 / 00293652.2013 .839577$. 
Zimmerman, Larry J., Karen D. Vitelli, and Julie Hollowell-Zimmer, eds. 2003. Ethical

Issues in Archaeology. Walnut Creek: AltaMira Press.

\author{
Zorgdrager, Nellejet 1997. De rettferdiges strid, Kautokeino 1852: Samisk motstand mot \\ norsk kolonialisme. Translated from Dutch by Trond Kirkeby-Garstad. Samiske samlinger,
}

vol. 18. Nesbru: Vett \& viten/Norsk folkemuseum.

\footnotetext{
${ }^{1}$ This paper uses images of human remains, which may be considered inappropriate by indigenous people (cf. Tamaki Makau-rau Accord). Although this issue does not seem to be of particular concern to Sámi, I do not want to underestimate the importance and sensitivity of the matter, potentially also for the Sámi. However, I find it necessary to employ such images to illuminate the emphasis on the material entanglements of the dead, which is central to this paper.

${ }^{2}$ When possible/adequate, place names are given in both Sámi and/or Norwegian, Swedish and Finnish throughout the paper.

${ }^{3}$ Hætta and Somby were buried November 19, 1854 (Parish registers of Kåfjord No. $161847-1857$ and Kautokeino No. 2 1843-1861).

${ }^{4}$ The skull of Hætta was exchanged for two Inuit skulls from Copenhagen University in 1856 (Schanche 2002c).

${ }^{5}$ Original in antiquated Sámi orthography: "Hoerra Jesus fasted munji”. Vicar Jacob Wetlesen supervised the execution in Alta.

${ }^{6}$ What constitutes a "case" is somewhat roughly defined in this context and limited to demands/requests forwarded in public or officially. In addition to those mentioned in the text, the actual cases are: reburial August 12, 2011 of human remains of a sixteenth-century woman in the original grave at Gransjön, Frostviken, north Sweden; reburial October 3, 2016 of the cranium of a seventeenth-century man from the cemetery of Jámetmielli, Guovdageaidnu/Kautokeino, in the churchyard of Guovdageaidnu/Kautokeino, north Norway; pending reburial of 21 crania from the mediaeval-to-nineteenth-century cemetery of Todd'suel/Gravholmen, Sør-Varanger, Finnmark, north Norway; pending reburial of 25 crania from Gamplatsen, Lycksele, north Sweden; anticipated reburial of human remains of two seventh-century individuals from Skjellesvik, Tysfjord, Nordland, north Norway; deposition of 12 mediaeval crania and some post-cranial bones from Rounala Churchyard, north Sweden, to Ájtte - Swedish Mountain and Sámi Museum; deposition 2001 of unknown number of undated skeletons/crania from graves/cemeteries in north Finland to Siida Sámi Museum, Aanaar/Inari, north Finland; anticipated transfer of cranium of allegedly nineteenth-century individual from Lycksele, north Sweden, to the Swedish Sámi parliament (decision 2009); request of reburial of skeletal remains of minimum 42 individuals excavated 2004-2016 from Silbojokk cemetery, AD 1635-1770,

Árjepluovve/Arjeplog, north Sweden; request of repatriation of human remains excavated 1992 from the old (alleged seventeenth-to-eighteenth-century) churchyard of Dálvvadis/Jokkmokk, north Sweden.

${ }^{7}$ Gustav Hallström investigated some of the graves in the early twentieth century (Hallström 1935).

${ }^{8}$ The Christianization of the Sámi is generally considered to have taken place between AD 1550 and AD 1750, although there were earlier attempts of various influence (see, e.g. Mundal 2012; Aronsson 2013; Hansen and Olsen 2014; Rasmussen 2016).
} 